NBER WORKING PAPER SERIES

TRADE AND STRUCTURAL INTERDEPENDENCE

BETWEEN THE U.S. AND THE NICS

William H. Branson

Working Paper No. 1282

NATIONAL BUREAU OF ECONOMIC RESEARCH

1050 Massachusetts Avenue

Cambridge, MA 02138

March 1984

The research reported here is part of the NBER's research program in International Studies and project in Productivity (World

Economy). Any opinions expressed are those of the author and not those of the National Bureau of Economic Research. 


\section{Trade and Structural Interdependence \\ Between the U.S. and the NICs}

\section{ABSTRACT}

During the decade since 1973, the U.S. economy has become increasingly interdependent with the newly industrializing countries (NICs) among the developing countries. These countries have had high investment ratios to GNP, financed mainly by domestic saving, but also partly by foreign borrowing. They have invested in manufacturing capacity, importing capital equipment. This increase in international demand for equipment has resulted in an increase of U.S. capital good exports to over 50 percent of all U.S. manufactures. In turn, exports of consumer manufactures by the NICs to the OECD countries have expanded rapidly. As the NICs grew during the 1970's, they imported capital goods from the U.S., and exported consumer manufactures to the U.S. This pattern of trade has strengthened the interdependence between the U.S. economy and the NICs.

The geographical pattern of U.S. trade with the NICs shows some interesting asymmetries. U.S. exports are relatively focused on Latin America, mainly Mexico, and imports on the Far Eastern NICs. A trade triangle has developed, with the U.S. exporting manufactures, mainly capital goods, to the Latin American NICs; who in turn sell raw materials on the world market. The Far Eastern NICs buy raw materials and sell manufactures, mainly consumer goods, to the U.S. Thus growth in the U.S. economy has become more interdependent with both the Latin American and Far Eastern NICs.

William H. Branson Woodrow Wilson School Princeton University Princeton, NJ 08544 609-452-4828 
Trade and Structural Interdependence

Between the U.S. and the NICs.*

1. Introduction and Summary.

During the decade since 1973, the U.S. economy has become increas-

ingly interdependent with the newly industrializing countries (NICs) among the developing countries. [See Table 24 for a list of identified NICs.] These countries have had high investment ratios to GNP, financed mainly by domestic saving, but also partly by foreign borrowing. They have invested in manufacturing capacity, importing capital equipment. This increase in international demand for equipment has resulted in an increase of U.S. capital good exports to over 50 percent of all U.S. manufactures; the 12 NICs enumerated in the tables in section 3 of this paper absorbed 22 percent of all U.S. capital goods exports in 1981.

In turn, exports of consumer manufactures by the NICs to the OECD countries have expanded rapidly. The 12 NICs provided half of U.S. imports of consumer manufacture (non-food, non-auto) in 1980, and 40 percent of Eurcpean imports. As the NICs grew during the 1970's, they imported capital goods from the U.S., and exported consumer manufactures to the U.S.

This pattern of trade has strengthened the interdependence between the U.S. economy and the NICs. In section 3 below we show that U.S. exports of manufactures are less balanced across commodities than European or Japanese exports, with high shares in the U.S. for capital goods and chemicals. The NICs are a major market area for these U.S. exports.

\footnotetext{
*Support from the NSF Division of Policy Research and Analysis is gratefully acknowledged.
} 
The geographical pattern of U.S. trade with the NICs also shows some interesting asymmetries. In overall trade in manufactures, the U.S. has a large surplus ( $\$ 12.2$ billion in 1980 ) in trade with the Latin American NICs (Argentina, Brazil, Colombia, Mexico), a small surplus ( $\$ 2.5$ billion) with the ASEAN countries, and a large deficit ( $\$ 11.3$ billion) with the Far Eastern NICs (Hong Kong, S. Korea, Taiwan). Thus the U.S. exports capital goods to the NICs and imports consumer goods from them, following broad lines of comparative advantage. But the exports are relatively focused on Latin America, mainly Mexico, and imports on the Far Eastern NICs. In the data of sections 3-5 a trade triangle appears, with the U.S. exporting manufactures, mainly capital goods, to the Latin American NICs; who in turn sell raw materials on the world market. The Far Eastern NICs buy raw materials and sell manufactures, mainly consumer goods, to the U.S. These patterns of interdependence should be a major focal point of U.S. foreign economic policy.

The data presented in sections $2-5$ below support this view of interdependence between the U.S. economy and the NICs, which differs from the relations of Europe or Japan with those countries. In section 2 we begin by describing investment and manufacturing-led growth in the NICs since 1970 or so. This is part of a broader pattern of growth in manufacturing in the developing countries that has left only the African primary producers dependent on a single primary export. Growth of manufacturing capacity, particularly in the NICs, has provided a market for exports of capital equipment.

In sections 3 and 4 we compare the evolution of the geographical and commodity composition of manufactures exports and imports of the 
U.S., Europe, and Japan. The NICs take a high proportion of U.S. and Japanese exports relative to European exports, with the U.S. relatively concentrated on capital goods and Latin America. The U.S. is the biggest market for NIC exports of manufactures, particularly consumer goods. The pattern of U.S. trade with the industrial NICs, disaggregated by commodity, is examined in section 5 . There we see the geographical imbalances mentioned above, which make growth in the U.S. economy interdependent with growth both in Latin America and among the Asian NICs. 


\section{The Rise of the NICs}

\subsection{Introduction.}

During the 1970 s the relative size of the manufacturing sector expanded in a broad range of developing countries. In a subset of these countries in Latin America and Asia, this growth made them significant producers of manufactures on a world scale by the end of the decade. This group has been labelled the newly industrializing countries, or NICs. In this section we analyze some aspects of the rise of the NICs that are important for the later discussion of their trade interactions with the OECD countries.

Growth in manufacturing capacity and trade in the developing countries, which will be documented below, seems to have reduced their tight dependence on OECD growth. While there is still a strong correlation between growth rates of industrial countries and the average across all developing countries, the correlation is less tight when we look at groups of developing countries. It is no longer clear who is the "engine" and who is the dead weight in the international growth process. Growth rate data since 1973 are summarized in Table 1 for areas of interest for the analysis below. The data for the industrial countries show the deepening stagnation in the OECD area, especially in Europe. For example, the West German economic institutes are forecasting a significant recover in 1984, with real GDP growing at 2-3 percent, and unemployment rising only slowly. In Europe, recovery has been redefined to mean only a small increase in unemployment! The average growth pattern over 
Table 1: $\quad$ Growth Rates of Real GDP of Selected Groups of Countries, $1978-80$.

\begin{tabular}{|c|c|c|c|c|}
\hline \multirow[b]{2}{*}{ Country Group } & \multicolumn{4}{|c|}{ Average annual percentage growth } \\
\hline & $1973-79$ & 1980 & 1981 & 1982 \\
\hline Industrial countries ${ }^{a}$ & 2.8 & 1.3 & 1.0 & -0.2 \\
\hline Developing countries & 5.1 & 6.1 & 2.0 & 1.9 \\
\hline Low-income & 5.1 & 6.1 & 3.7 & 3.7 \\
\hline $\begin{array}{l}\text { Middle-income oil } \\
\text { importers }\end{array}$ & 5.5 & 4.2 & 1.1 & 1.1 \\
\hline $\begin{array}{l}\text { East asia and Pacific } \\
\text { Middle East and North }\end{array}$ & 8.5 & 3.6 & 6.9 & 4.2 \\
\hline Africa & 2.9 & 4.7 & 0.1 & 2.7 \\
\hline Western Hemisphere & 4.9 & 5.7 & -2.4 & -1.2 \\
\hline $\begin{array}{l}\text { Major exporters of } \\
\text { manufactures } b\end{array}$ & 6.4 & 4.5 & -0.2 & 0.2 \\
\hline
\end{tabular}

a. All data are averages weighted by real GDP.

b. IMF classification of major exporters of manufactures.

Sources: World Bank, World Development Report, 1983, Table 2.1. IMF, Annual Report, 1983, Table 2. 
all developing countries is roughly similar to that of the industrial countries, but there are important differences in timing. While the OECD countries, led by the United States, went deep into recession in 1982 , growth was about the same as in 1981 in the developing countries.

The subgroups of developing countries in Table 1 show a wide diversity of growth patterns relative to the industrial countries. The low-income and the Western Hemisphere countries show a rise in the growth rate in 1980 , and the East Asian and Pacific countries show a sharp rise in 1981. The middle-income oil importers in the Middle East and North Africa, and the major exporters of manufactures (the NICs) show an increase in the growth rate in 1982, when the OECD slump deepened. Thus the pattern of growth among the subgroups of Table 1 does not mirror the movement in the industrial countries. The increase in growth in the developing countries relative to the industrial countries in 1982 could lead us to ask if the rules of engine and dead weight have not been reversed.

In the rest of this section of the paper, we will look in more detail at the structure of growth in the NICs, the development of the manufacturing sector in the NICs and in a broader sample of developing countries, and the financing of this growth. The facts to be presented are all well-known by now; the point here is to present them in a way that will make clear the connection between these developments and the evolution of the structure of trade between the NICs especially in Asia, and the OECD countries especially the United States. 


\subsection{Growth in the NICs, 1970-81.}

There are about as many lists of which countries are NICs as there are authors on the topic of their emergence and growth. So we have an initial problem of identification of countries. There is also in the background of this literature a deeper question of whether the identification has not been done purely on an ex post basis by looking at a narrow set of indicators related to growth in manufacturing capacity. It is quite possible that the category NICs does not exist as measured by other characteristics of the economy. For example, on the "distortion index" of the World Bank, of the NICs listed in Table 2, Thailand, Korea, Malaysia, the Philippines and Colombia are in the low-distortion category; Indonesia, India, Brazil, and Mexico are "middle-distortion" countries; Argentina is the only "high-distortion" country. [World Development Report, 1983, P. 60]. Does this grouping imply that we can categorize NICs as relatively "low-distortion" countries? The answer is not clear. An urgent topic for research in this area would be on analysis using a "clustering algorithm" grouping countries by a wide range of economic indicators, such as the entire set of World Bank Indicators, to see if a category "NICs" emerges statistically.

In the face of these reservations, we must proceed, so I have decided to adopt the list of NICs provided by Colin Bradford (1982), which includes countries which are on most lists. Bradford further introduces the subsets of existing NICs and potential, or "New NICs," as they are labelled in Table 2. The categories in Table 2 are also broken down by the World Banks groupings by income level. Taiwan is omitted because it 
no Longer appears in the World Bank data; it is included later in the analysis of trade data.

The growth rates of real GDP, investment, and manufacturing output in the NICs are summarized in Table 2 for the period 1970-81. Among the NICs identified there, the only countries with lower growth rates than thejr income-group average were Argentina in all three categories and Thailand in investment growth. Comparing growth rates across columns, only Singapore shows slower investment growth than GDP growth, and only Argentina shows slower growth of manufacturing output than GDP growth. [Is Argentina already deindustrializing?] .

The impression left by the data of Table 2 is of investment-led growth in the NICs, with manufacturing output growing faster than GDP. Next we see the effects on the structure of output and exports, and how this growth was financed.

\subsection{The Shift toward Manufacturing.}

The increase in the manufacturing sector as a fraction of GDP and, even more strikingly, of exports among the NICs is shown in Table 3 . The increase in the share of manufacturing in GDP from 1960 to 1981 was greater than the average for the income group in all of the identified NICs except Brazil and Argentina, where it actually decreased.

The last two columns of Table 3 show the increase in the share of manufactures in exports. Here the numbers are striking. Even in countries where the manufacturing share of output did not rise significantly, the export share did. Indonesia, whose exports came to be dominated by oil, in a mild version of the "Dutch disease", is the only country with a 
Table 2: Growth Rates of GDP, Investment, and Manufacturing Output, 1970-81 (percent per year).

\begin{tabular}{|c|c|c|c|}
\hline $\begin{array}{l}\text { Group or } \\
\text { Country }\end{array}$ & GDP & $\begin{array}{l}\text { Gross Domestic } \\
\text { Investment }\end{array}$ & $\begin{array}{c}\text { Manufacturing } \\
\text { Output }\end{array}$ \\
\hline \multicolumn{4}{|l|}{ NICs } \\
\hline$\frac{\text { Low income (average) }}{\text { India }}$ & $\begin{array}{l}3.6 \\
3.6\end{array}$ & $\begin{array}{l}3.7 \\
4.9\end{array}$ & $\begin{array}{l}2.8 \\
5.0\end{array}$ \\
\hline $\begin{array}{l}\text { Upper middle } \\
\text { income (average) }\end{array}$ & 5.6 & 7.2 & 6.3 \\
\hline $\begin{array}{l}\text { S. Korea } \\
\text { Hong Kong } \\
\text { Singapore } \\
\text { Brazil } \\
\text { Mexico } \\
\text { Argentina }\end{array}$ & $\begin{array}{l}9.1 \\
9.9 \\
8.5 \\
8.4 \\
6.5 \\
1.9\end{array}$ & $\begin{array}{r}12.2 \\
14.1 \\
7.2 \\
7.9 \\
9.0 \\
2.5\end{array}$ & $\begin{array}{r}15.6 \\
10.1 \\
9.7 \\
8.7 \\
7.1 \\
0.7\end{array}$ \\
\hline \multicolumn{4}{|l|}{ New NICs } \\
\hline $\begin{array}{l}\text { Lower middle } \\
\text { income (average) }\end{array}$ & 5.6 & 8.2 & 5.8 \\
\hline $\begin{array}{l}\text { Indonesia } \\
\text { Thailand } \\
\text { Philippines } \\
\text { Columbia }\end{array}$ & $\begin{array}{l}7.8 \\
7.2 \\
6.2 \\
5.7\end{array}$ & $\begin{array}{r}14.0 \\
7.5 \\
10.1 \\
10.8\end{array}$ & $\begin{array}{r}13.9 \\
10.3 \\
6.9 \\
5.7\end{array}$ \\
\hline \multicolumn{4}{|l|}{$\begin{array}{l}\text { Upper middle } \\
\text { income }\end{array}$} \\
\hline Malaysia & 7.8 & 10.4 & 11.1 \\
\hline
\end{tabular}

a. Average for low-income countries other than China and India. Source: World Bank, World Development Report, 1983. 
Table 3: Manufacturing Output and Exports in the NICs, 1960 and $1980-81$.

\begin{tabular}{|c|c|c|c|c|}
\hline \multirow[t]{2}{*}{$\begin{array}{l}\text { Group or } \\
\text { Country }\end{array}$} & $\begin{array}{c}\text { Manutacturing } \\
\% \text { of GDP }\end{array}$ & Output as & \multirow{2}{*}{$\begin{array}{l}\text { Manufactures } \\
\frac{\% \text { of Goods }}{1960}\end{array}$} & \multirow{2}{*}{$\begin{array}{l}\text { Exports as } \\
\text { Exports } \\
1980\end{array}$} \\
\hline & 1960 & 1981 & & \\
\hline \multicolumn{5}{|l|}{ NICs } \\
\hline $\begin{array}{l}\text { Low income (average) } \\
\text { India }\end{array}$ & $\begin{array}{r}9 \\
14\end{array}$ & $\begin{array}{l}10 \\
18\end{array}$ & $\begin{array}{r}9 \\
45\end{array}$ & $\begin{array}{l}29 \\
59\end{array}$ \\
\hline $\begin{array}{l}\text { Upper middle } \\
\text { income (average) }\end{array}$ & 23 & 24 & 16 & 45 \\
\hline $\begin{array}{l}\text { S. Korea } \\
\text { Hong Kong } \\
\text { Singapore } \\
\text { Brazil } \\
\text { Mexico } \\
\text { Argentina }\end{array}$ & $\begin{array}{l}14 \\
27 \\
12 \\
26 \\
19 \\
32\end{array}$ & $\begin{array}{l}28 \\
- \\
30 \\
27 \\
22 \\
25\end{array}$ & $\begin{array}{r}14 \\
80 \\
26 \\
3 \\
12 \\
4\end{array}$ & $\begin{array}{l}90 \\
93 \\
54 \\
39 \\
38 \\
23\end{array}$ \\
\hline \multicolumn{5}{|l|}{ New NICs } \\
\hline $\begin{array}{l}\text { Lower middle } \\
\text { income (average) }\end{array}$ & 15 & 17 & 4 & 18 \\
\hline $\begin{array}{l}\text { Indonesia } \\
\text { Thailand } \\
\text { Philippines } \\
\text { Columbia }\end{array}$ & $\begin{array}{l}(0) \\
13 \\
20 \\
8\end{array}$ & $\begin{array}{l}12 \\
20 \\
25 \\
14\end{array}$ & $\begin{array}{l}0 \\
2 \\
4 \\
2\end{array}$ & $\begin{array}{r}2 \\
29 \\
37 \\
20\end{array}$ \\
\hline \multicolumn{5}{|l|}{$\begin{array}{l}\text { Upper middle } \\
\text { income }\end{array}$} \\
\hline Malaysia & 9 & 18 & 6 & 19 \\
\hline
\end{tabular}

a. Average for low-income economies other than china and India.

Source: World Bank, World Development Report, 1983. 
small increase in the manufacturing share.

This shift toward manufacturing exports is not limited to the NICs, as we see in Table 4 and Figures 1-4, taken trom James Riedel (1982). Table 4 shows the evolution of the distribution of non-fuel exports of the developing countries from 1955 to 1978. Over that period, manufactures increased from 10 to 45 percent of developing country exports. Noting that four Asian NICs--Hong Kong, S. Korea, Singapore and Taiwan-account for over 60 percent of developing country manufactures exports, Riedel went on to study a 54-country sample that excludes those four. The sample was divided into 11 "balanced exporters," 22 non-African primary exporters, and 20 African primary exporters. The evolution of the average export structure of the entire sample is shown in Figure 1 . The increase in manufactures share from 7 percent in 1960 to 18 percent in 1976-78 is balanced by the decrease in the share of the largest single primary export from 47 to 36 percent. The experience of the "balanced exporters," which include Brazil, India, and Mexico from our list of NICs, is shown in Figure 2. The manufactures share rises from 15 to 39 percent, and the largest single primary share falls from 43 to 22 percent. In Figure 4 we see that the non-African primary producers, which include Argentina, Malaysia, Philippines, and Thailand from our list, increased their manufactures share from 4 to 16 percent, and reduced the largest single primary share from 46 to 32 percent. Only the African primary producers, shown in Figure 3, remain heavily dependent on the largest single primary export. We will see below that this is the main market among the developing countries for European exports. 
Table 4: $\quad$ Structure of Developing Country Exports, 1955-78 (percentages).

\begin{tabular}{lcccc}
\hline Export Category & 1955 & 1960 & 1970 & 1978 \\
\hline Total Non-fuel Exports & 100 & 100 & 100 & 100 \\
Food & 49 & 47 & 40 & 35 \\
Agricultural Raw Materials & 28 & 25 & 15 & 10 \\
Minerals, Oils & 13 & 15 & 18 & 10 \\
Manufactures & 10 & 13 & 27 & 45 \\
\end{tabular}

Source: Riedel (1982), Table 1, taken from UNCTAD, Handbook of Trade and Development Statistics, 1972, 1979, 1980. 


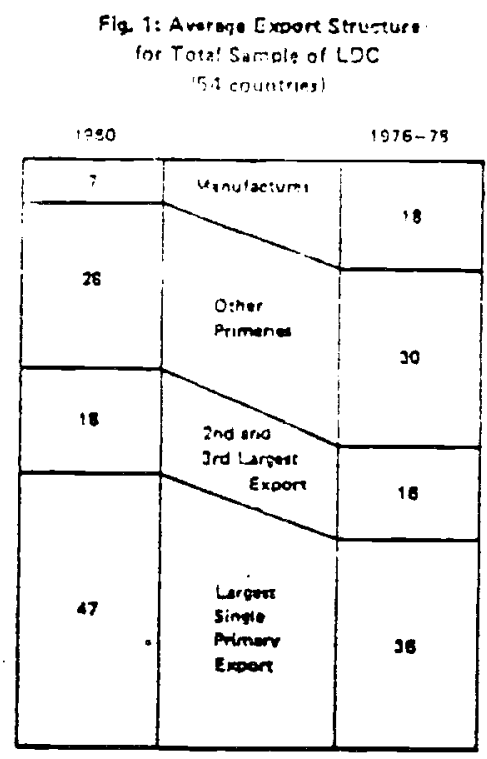

F7. 3: Amones Expor Structurn for African Primer Expors (20 eountived)

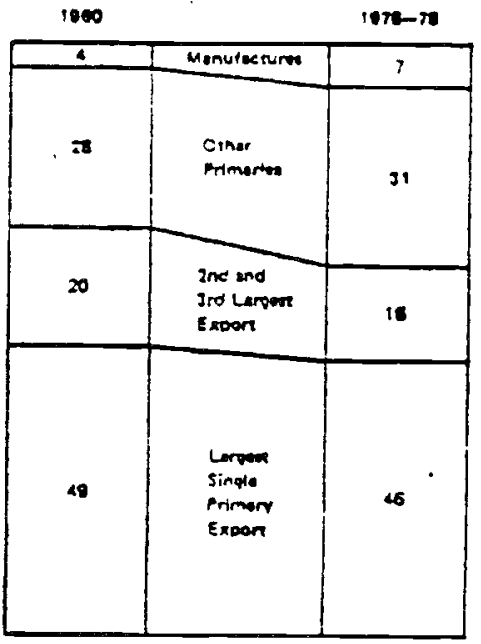

Fia. 2: Aversew Expon s:ruse ure

in: ?alanced Fxnorters in rountresl

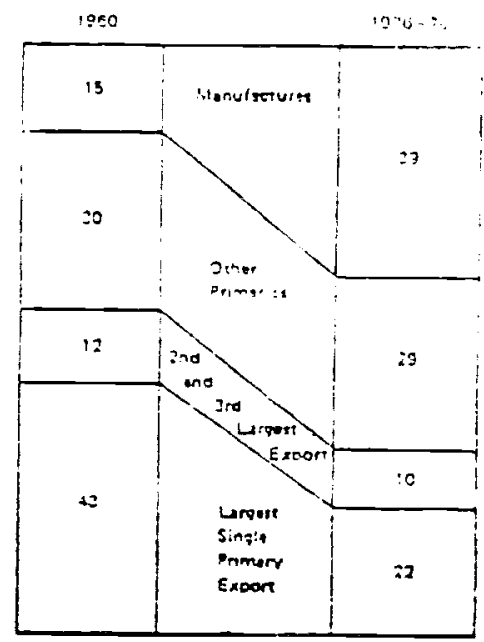

Fio 4: A vernes Export Striscture for Man-African Primary Exoartere (23 ecuntrien)

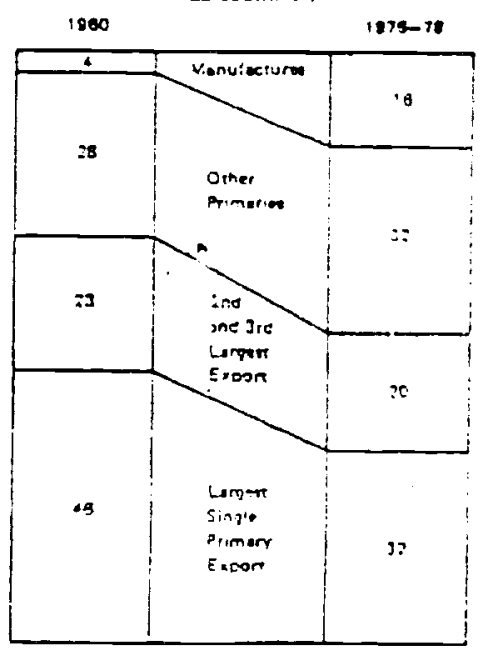

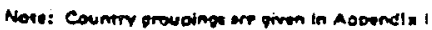

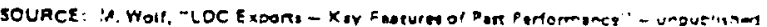

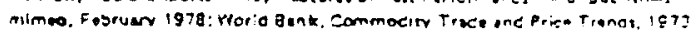

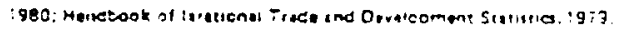


The developing countries on average, and especially the NICs, grew rapidly. in the 1970 s, even in the face of stagnation in the OECD area. Investment and manufacturing output grew faster than GDP in the NICs, and the manufacturing share of output and exports increased substantially. In later sections of the paper we link this growth in manufacturing output to demand for capital goods exports from the OECD countries, particularly the U.S.

\subsection{Investment, Saving, and Foreign Borrowing.}

Rapid growth in investment in the NICs has been associated with relatively high shares of investment in GDP, financed partly by high domestic saving rates and partly by foreign borrowing. The data for 1981 are summarized in Table 5. In the first column we see that among the identified NICs, only Brazil and Indonesia had investment rates lower than their group averages. The 25 percent investment share for middle income developing countries is itself high by international standards.

The second and third columns in Table 5 show how investment in 1981 was financed. The upper middle income NICs, including Malaysia, have saving rates not much different from the group average of 24 percent. Singapore is higher and Brazil lower. So this group experienced a higherthan-average foreign capital inflow, as shown in the last column of Table 5. On the other hand, the lower-income NICs, including India, all have saving rates much higher than their group average, and lower-than-average capital inflow. 
Table 5: Investment and Saving in NICs, 1981 (percent of GDP)

\begin{tabular}{|c|c|c|c|}
\hline $\begin{array}{l}\text { Group or } \\
\text { Country }\end{array}$ & $\begin{array}{l}\text { Gross } \\
\text { Investment }\end{array}$ & $\begin{array}{c}\text { Gross Domestic } \\
\text { Saving }\end{array}$ & $\begin{array}{l}\text { Foreign Borrowing } \\
\quad \text { or Transfer }\end{array}$ \\
\hline \multicolumn{4}{|l|}{ NICs } \\
\hline Low income (average) & 14 & 7 & 7 \\
\hline India & 23. & 20 & 3 \\
\hline $\begin{array}{l}\text { Upper middle } \\
\text { income (average) }\end{array}$ & 25 & 24 & 1 \\
\hline S. Korea & 26 & 22 & 4 \\
\hline Hong Kong & 30 & 24 & 6 \\
\hline Singapore & 42 & 33 & 9 \\
\hline Brazil & 20 & 19 & 1 \\
\hline Mexico & 25 & 23 & 2 \\
\hline Argentina & 26 & 23 & 3 \\
\hline \multicolumn{4}{|l|}{ New NICs } \\
\hline \multicolumn{4}{|l|}{ Lower middle } \\
\hline income (average) & 25 & 19 & 6 \\
\hline Indonesia & 21 & 23 & -2 \\
\hline Thailand & 28 & 23 & 5 \\
\hline Philippines & 30 & 25 & 5 \\
\hline Colombia & 28 & 24 & 4 \\
\hline \multicolumn{4}{|l|}{$\frac{\text { Upper middle }}{\text { income }}$} \\
\hline Malaysia & 32 & 26 & 6 \\
\hline
\end{tabular}

a. Average for low-income economies other than China and India. Source: World Bank, World Development Report, 1983. 
The data of Table 5 confirm the impression that the NICs have experienced high saving rates, around 23 or 24 percent, and even higher investment rates, grouped around 28 percent or so. The difference has been financed by foreign investment of around 5 percent of GDP. The main exceptions are Indonesia, which has on balance been investing abroad, and Brazil, with lower rates of investment and saving. Thus in general international capital has flowed toward countries with high investment rates, financed mainly by domestic saving; the NICs are good examples. The consequences of this pattern of investment-led growth partly financed by foreign borrowing are summarized in the debt and debt service data of Table 6 . The first two columns show external public and publiclyguaranteed debt in billions of dollars in 1970 and 1981 . The middle two columns show this debt as a fraction of GDP. The last two columns show the debt service ratio to export earnings. Since the data covers public debt only, they seriously understate total national foreign debt in countries with extensive borrowing by the private sector, such as Brazil and Mexico.

While Brazil, Mexico, and Argentina do not stand out in the columns showing debt-GNP ratios, they do stand out in the debt-service data, reflecting their lower levels of exports relative to GNP. All of the upper middle income NICs show increases in the debt-GNP ratio from 1970 to 1980 . Among them, Hong Kong and Singapore have markedly low debt-GNP and especially debt service ratios. Thailand and the Philippines also show increases in both ratios from 1970 to 1981. The exceptions are India, with a marked decrease in both ratios, Colombia, with debt and GNP growing at the same rate from 1970 to 1981 and the debt service ratio falling, and 
Table 6: $\quad$ Externa1 Public Debt and Debt Service Ratios.

\begin{tabular}{|c|c|c|c|c|c|c|}
\hline \multirow[t]{2}{*}{$\begin{array}{l}\text { Group or } \\
\text { Country }\end{array}$} & \multicolumn{2}{|c|}{$\begin{array}{l}\text { External Pub } \\
\text { \$ billion }\end{array}$} & \multicolumn{2}{|c|}{$\begin{array}{l}\text { Debt } \\
\% \text { of GNP } \\
\end{array}$} & \multicolumn{2}{|c|}{$\begin{array}{l}\text { Debt Service } \\
\text { Ratioa } \\
\end{array}$} \\
\hline & 1970 & 1981 & 1970 & 1981 & 1970 & 1981 \\
\hline NICs & & & & & & \\
\hline$\underline{\text { Low income (average) }}^{a}$ & - & - & 22.0 & 28.3 & 12.5 & 8.8 \\
\hline India & 7.9 & 18.0 & 14.9 & 10.8 & 20.9 & 8.6 \\
\hline $\begin{array}{l}\text { Upper middle } \\
\text { income (average) }\end{array}$ & - & - & 12.4 & 17.8 & 10.1 & 15.4 \\
\hline $\begin{array}{l}\text { S. Korea } \\
\text { Hong Kong } \\
\text { Singapore } \\
\text { Brazil } \\
\text { Mexico } \\
\text { Argentina }\end{array}$ & $\begin{array}{l}1.8 \\
(0) \\
0.1 \\
3.2 \\
3.2 \\
1.9\end{array}$ & $\begin{array}{r}20.0 \\
0.3 \\
1.3 \\
43.8 \\
42.7 \\
10.5\end{array}$ & $\begin{array}{r}20.8 \\
0.1 \\
7.9 \\
7.1 \\
9.1 \\
8.2\end{array}$ & $\begin{array}{r}32.1 \\
1.2 \\
10.2 \\
16.0 \\
18.5 \\
8.7\end{array}$ & $\begin{array}{r}19.4 \\
(0) \\
0.6 \\
12.5 \\
23.6 \\
21.5\end{array}$ & $\begin{array}{r}13.1 \\
0.7 \\
0.8 \\
31.9 \\
28.2 \\
18.2\end{array}$ \\
\hline \multicolumn{7}{|l|}{ New MICs } \\
\hline $\begin{array}{l}\text { Lower Middle } \\
\text { income (average) }\end{array}$ & - & - & 15.6 & 23.2 & 9.3 & 12.5 \\
\hline $\begin{array}{l}\text { Indonesia } \\
\text { Thailand } \\
\text { Philippines } \\
\text { Colombia }\end{array}$ & $\begin{array}{l}2.4 \\
0.3 \\
0.6 \\
0.5\end{array}$ & $\begin{array}{r}15.5 \\
5.2 \\
7.4 \\
3.2\end{array}$ & $\begin{array}{r}27.1 \\
4.9 \\
9.0 \\
38.2\end{array}$ & $\begin{array}{l}19.0 \\
14.4 \\
19.3 \\
38.0\end{array}$ & $\begin{array}{r}6.9 \\
3.4 \\
7.4 \\
17.5\end{array}$ & $\begin{array}{r}8.2 \\
6.7 \\
9.9 \\
13.9\end{array}$ \\
\hline \multicolumn{7}{|l|}{$\begin{array}{l}\text { Upper middle } \\
\text { income }\end{array}$} \\
\hline Malaysia & 0.4 & 4.6 & 10.0 & 19.2 & 3.6 & 3.1 \\
\hline
\end{tabular}

a. Average for low-income countries other than China and India. Source: World Bank, World Development Report, 1983. 
Indonesia with a falling debt-GNP ratio and a rising debt service ratio.

It is clear from the data of Table 6 that while in general the NICs have grown with foreign borrowing, their debt positions in the early 1980 s varied significantly, from the low-exposure positions of Hong Kong, Sinapore, and Malaysia, to the crisis conditions of Argentina, Brazil, and Mexico. As we see below, U.S. exports are relatively more oriented toward the Latin American NICs, and Japan's toward the Asian NICs. Thus while the U.S. economy has become more interdependent with the NICs through trade, the Latin American orientation of its exports leaves it more sensitive than Europe or Japan to a Latin American debt squeeze.

3. The Structure of OECD Exports.

\subsection{Introduction.}

During the past two decades, the share of U.S. exports going to the NICs has increased substantially, while the NICs share of Japanese exports has remained constant, and the NIC's share of European exports has decreased. In the the U.S. case, the NIC's share of each one-digit SITC category of manufactures exports has risen. By 1981 the NICs absorbed 31 percent of U.S. exports of chemicals and 22 percent of U.S. exports of capital goods, the two biggest single U.S. export categories. Overall, by 1981 the NICs share of manufactured exports was 25 percent for Japan, 21 percent for the U.S., 13 percent for OECD Europe, and 9 percent for the EEC. These data reflect one aspect of the increasing interdependence of the U.S. and Japanese economies with the rapid1y-growing developing countries, especially as compared with Europe. 
In this section we summarize the comparative data on U.S., Japanese, and European exports to the NICs, especially the Asian NICs. We begin by looking at the data disaggregated by one-digit SITC group and destination, and then look at the distribution across commodity groups of the exports of manufactures of each of the three main OECD areas.

\subsection{Distribution of Total Exports and Total Manufactures Exports by Destination.}

The evolution of exports and their fraction going to the NICs and the Asian NICs from 1964 to 1981 is shown for OECD Europe and the EEC, the U.S., and Japan in Table 7 for total exports and Table 8 for total manufactures exports. Intra-area trade has been excluded from the European data to make them comparable with the U.S. and Japanese data. Thus EEC exports can be larger than OECD Europe exports because of the exclusion of EEC exports to other European countries from the OECD Europe data. The EEC here is the Community of nine countries, before the accession of Greece.

In Table 7 we see that U.S. total exports grew a little less rapidly than Europes from 1964 to 1981. In 1964 the totals for the U.S. and OECD Europe are nearly equal, but in 1981, U.S. exports were 84 percent of OECD Europe's. The differential growth took place during the 1964-73 period of rapid European growth; the ratio of U.S. exports to European exports has stayed constant at about 85 percent since 1973. Japan's total exports have grown much faster than Europe's or those of the U.S., as is well known. In 1964 Japan's exports were about 25 percent of the U.S. total; this ratio rose to 52 percent in 1973 and 67 
Table 7: Distribution of Total Exports

\begin{tabular}{|c|c|c|c|c|c|c|}
\hline \multirow{2}{*}{$\begin{array}{l}\text { Area or } \\
\text { Country }\end{array}$} & \multicolumn{2}{|c|}{1964} & \multicolumn{2}{|c|}{1973} & \multicolumn{2}{|c|}{1981} \\
\hline & $\$ \mathrm{Bi}$ & $\frac{\mathrm{g}}{\mathrm{g}}$ & $\$ \mathrm{Bi}$ & $\overline{\frac{9}{8}}$ & $\overline{\$ B i 1}$ & $\mathrm{n}$ \\
\hline \multicolumn{7}{|l|}{ OECD Europe } \\
\hline World & 25.0 & 100.0 & 81.0 & 100.0 & 268.3 & 100.0 \\
\hline NICs & 3.7 & 14.8 & 9.9 & 12.2 & 34.0 & 12.7 \\
\hline Asian NICs & 2.4 & 9.6 & 5.5 & 6.8 & 21.5 & 8.0 \\
\hline
\end{tabular}

EEC

Wor ld

30.4

100.0

98.1

100.0

295.6

100.0

NICs

3.1

8.1

8.3

27.5

9.3

Asian NICs

U.S.A.

Wor Id

NICs

Asian NICs
2.1

6.5

6.6

18.0

6.1

26.1

4.3

2.4

6.9

100.0

16.5

10.4

70.2

4.5

5.4

100.0
16.4
7.7

225.8

47.1

22.3

100.0

20.9

9.9

\section{Japan}

World
NICs

Asian NICs
6.7

1.6

1.5
100.0

23.9

22.4
36.8

9.7

8.6
100.0

26.4

23.4
151.9

37.7

33.3
100.0

24.8

21.9

Source: OECD Data Tape 
percent in 1981. This growth of Japanese and European exports relative to the U.S. was a natural result of recovery and development in Europe and Japan, as discussed in Branson (1981).

More interesting here is the distribution of exports by destination. The NIC share of OECD Europe and EEC exports fell from 1964 to 1973, and then rose a bit to 12.7 percent for OECD Europe and 9.3 percent for the EEC by 1981. The NIC share of Japanese exports has remained at about 25 percent from 1964 to 1981. The NIC share of U.S. exports was about 16 percent in 1964 and 1973, but grew to 21 percent by 1981 . Three initial observations can be made from the data of Table 7 . First, the shares of European and Japanese exports going to the NICs have remained roughly constant, low for Europe and high for Japan. Second, the NIC share of U.S. exports has increased markedly since 1973. Third, about half the 21 percent of U.S. exports to the NICs go to Asia, the other half to Latin America.

The distributional pattern of total manufactures exports, shown in Table 8 , is similar to the pattern in Table 7 . Comparison of the two tables shows that in 1981 manufactures account for 95 percent of Japanese exports, 82 percent of OECD exports, and 71 percent of U.S. exports. Agriculture and raw materials account for a higher fraction of U.S. exports than they do in Europe or Japan.

The share of European and EEC manufactures exports going to the NICs fell from 1964 to 1973 , and then rose a bit to 1981 . The NIC share of Japanese manufactures exports stayed at about 27 percent for 1964 to 1973, and fell to 24.4 percent in 1981 . The NIC share of U.S. exports of manufactures fell a bit from 1964 to 1973, but then increased sharply 
Table 8: Distribution of Exports of Manufactures

Area or

Country

\section{OECD Europe}

World

NICS

Asian NICS

$\frac{1964}{\$ \text { Bilion }}$

21.0

3.5

2.2

25.6

2.9

1.7

Asian NICs

U.S.A.

$$
\text { World }
$$

NICS

Asian NICs

17.2
2.8
1.2

1.2
100.0

69.5

16.7

9.0

10.5

5.0

100.0

84.4

11.3

7.5

7.0

4.3

100.0

46.5

16.3

7.2

7.0

3.3

100.0

27.1

33.8

9.3

25.4

8.6
100.0

12.9

7.2

219.5

31.7

19.9 $\frac{1981}{\$ \text { Bilition }}$

\section{Japan}

Worla

5.9

$100.0 \quad 160.0$

100.0

15.5

34.9

21.8

7.1

14.9

9.3

NICS

1. 6

1.5

$100.0 \quad 144.9$

100.0

$27.4 \quad 35.4$

24.4

Asian NICs

1.5

25.4

30.9 .

21.3 
to nearly 22 percent by 1981, with nearly half going to the Asian NICs.

The fraction of U.S. manufactures exports going to the incipient NICs in 1964 was the same as OECD Europe's. But as the NICs grew, the share of U.S. manufactures exports to them also grew. By 1981 this share was similar to the NIC share of Japanese manufactures exports, with the U.S. relatively more concentrated in Latin America, and Japan in Asia.

\subsection{Disaggregation of the Distribution of Manufactures} Exports by Destination.

The distribution of manufactures exports by (approximately) onedigit SITC code is shown in Tables 9-13 for Europe, Japan, and the U.S. The exact definition of the categories is given in the note to Table 14 . Rather than discuss each table exhaustively, I will attempt to bring forward the major points.

Beginning with chemicals in Table 9, we see that the U.S. and Europe are major exporters, and Japan is not. The NIC share of U.S. chemicals exports is twice that of OECD Europe, at 30.9 percent, and Japanese exports are highly concentrated on the Asian NICs. In Table 10 we see that Europe is the biggest exporter of industrial materials, with Japan second and the U.S. third. The NIC share of Japan's exports is high and Europe's low, with both concentrated on the Asian NICs. The NIC share of U.S. exports is intermediate, and is concentrated on Latin America.

The important category of capital goods is shown in Table 11. As the NICs industrialize, they import capital goods. In 1981, U.S. and European exports of capital goods were about the same--\$82.2 billion for 
24.

Table 9: Distribution of Exports of Chemical Products (SITC 5)

\begin{tabular}{|c|c|c|c|c|c|c|}
\hline \multirow{2}{*}{$\begin{array}{l}\text { Area or } \\
\text { Country }\end{array}$} & \multicolumn{2}{|l|}{1964} & \multicolumn{2}{|l|}{1973} & \multicolumn{2}{|l|}{1981} \\
\hline & \$Billion & $\frac{\bar{g}}{0}$ & \$ Billion & $\frac{9}{6}$ & \$ Billion & $\frac{9}{\partial}$ \\
\hline OECD Europe & & & & & & \\
\hline World & 2.8 & 100.0 & 9.2 & 100.0. & 30.2 & 100.0 \\
\hline NICs & 0.6 & 21.4 & 1.7 & 18.5 & 4.9 & 16.2 \\
\hline Asian NICs & 0.3 & 10.7 & 0.9 & 9.8 & 3.3 & 10.9 \\
\hline
\end{tabular}

EEC

$\begin{array}{lrrrrrr}\text { World } & 3.3 & 100.0 & 11.3 & 100.0 & 34.4 & 100.0 \\ \text { NICs } & 0.4 & 21.1 & 1.5 & 13.3 & 4.1 & 11.9 \\ \text { Asian NICs } & 0.2 & 6.0 & 0.8 & 7.1 & 2.9 & 8.4\end{array}$

U.S.A.

$\begin{array}{lrrrrrr}\text { World } & 2.4 & 100.0 & 5.7 & 100.0 & 23.3 & 100.0 \\ \text { NICs } & 0.5 & 20.8 & 0.9 & 15.8 & 7.2 & 30.9 \\ \text { Asian NICs } & 0.3 & 12.5 & 0.2 & 3.5 & 4.2 & 18.0\end{array}$

Japan

\begin{tabular}{lrrrrrr} 
World & 0.4 & 100.0 & 2.1 & 100.0 & 6.8 & 100.0 \\
NICs & 0.2 & 50.0 & 1.1 & 52.3 & 3.1 & 45.6 \\
Asian NICs & 0.2 & 50.0 & 0.9 & 42.9 & 3.0 & 44.1 \\
\hline
\end{tabular}

Source: OECD Data Tape 
25.

Table 10: Distribution of Exports of Industrial Materials (SITC 6)

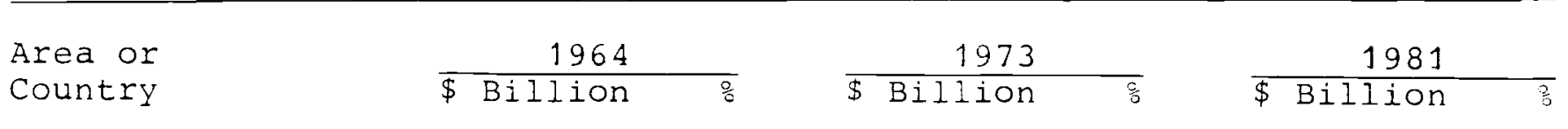

\section{OECD Europe}

$\begin{array}{lrrrrrr}\text { World } & 5.8 & 100.0 & 18.0 & 100.0 & 52.5 & 100.0 \\ \text { NICs } & 0.7 & 21.1 & 1.6 & 8.9 & 6.7 & 12.8 \\ \text { Asian NICs } & 0.6 & 10.3 & 0.9 & 5.0 & 4.6 & 8.8\end{array}$

$\underline{E E C}$

$\begin{array}{lrrrrrr}\text { World } & 6.9 & 100.0 & 21.7 & 100.0 & 55.0 & 100.0 \\ \text { NICs } & 0.6 & 8.7 & 1.4 & 6.5 & 5.0 & 9.1 \\ \text { Asian NICs } & 0.3 & 4.4 & 1.1 & 5.1 & 3.3 & 6.0\end{array}$

U.S.A.

$\begin{array}{lrrrrrr}\text { World } & 3.0 & 100.0 & 6.8 & 100.0 & 20.2 & 100.0 \\ \text { NICs } & 0.5 & 16.7 & 1.1 & 16.2 & 4.3 & 21.3 \\ \text { Asian NICs } & 0.3 & 10.0 & 0.4 & 5.9 & 1.4 & 6.9\end{array}$

$\underline{\text { Japan }}$

$\begin{array}{lrrrrrr}\text { World } & 2.7 & 100.0 & 10.4 & 100.0 & 32.7 & 100.0 \\ \text { NICs } & 0.7 & 25.9 & 3.7 & 35.6 & 10.2 & 31.2 \\ \text { Asian NICs } & 0.7 & 25.0 & 3.3 & 31.7 & 9.0 & 22.5\end{array}$

Source: OECD Data Tape 
the U.S. and $\$ 84.7$ billion for Europe--and Japanese exports were $\$ 51.7$ billion.

Both the growth since 1973 and the distribution of these exports are interesting. As we see in Table 14 below, capital goods are 51.4 percent of U.S., 38.6 percent of European, and 35.7 percent of Japanese manufactures exports in 1981. First, let us compare OECD Europe and the U.S. In 1973 European capital goods exports were 13 percent greater than the U.S., and the NIC share of European exports was also greater than that of U.S. exports. By 1981 European exports were 3 percent greater than the U.S., and the NIC share of U.S. exports was greater than that of European exports, with the U.S. relatively concentrated in Latin America. Now, let us compare Japan and the U.S. In 1973 Japanese exports of capital goods were 53 percent of the U.S.; by 1981 this ratio rose to 63 percent. Japan's exports remained highly concentrated on the Asian NICs. The total of NIC share of U.S. capital goods exports grew faster than that of Japan, but the U.S. also grew more concentrated on Latin America.

Thus in capital goods exports, U.S. total growth from 1973 to 1981 was slower than Japan's but faster than Europe's. The growth of U.S. exports to the NICs was about the same as that of Japan, but is significantly greater than that of Europe. This suggests that the U.S. was maintaining its competitive position vis-a-vis Japan, and both were improving relative to Europe in capital goods. But the concentration of the U.S. on the Latin American NICs, combined with the debt crisis of Argentina, Brazil, and especially Mexico, provides a serious short-run threat to this otherwise optimistic assessment of the U.S. position. 
27.

Table 11: Distribution of Exports of Capital Goods (SITC 7 Less 78)

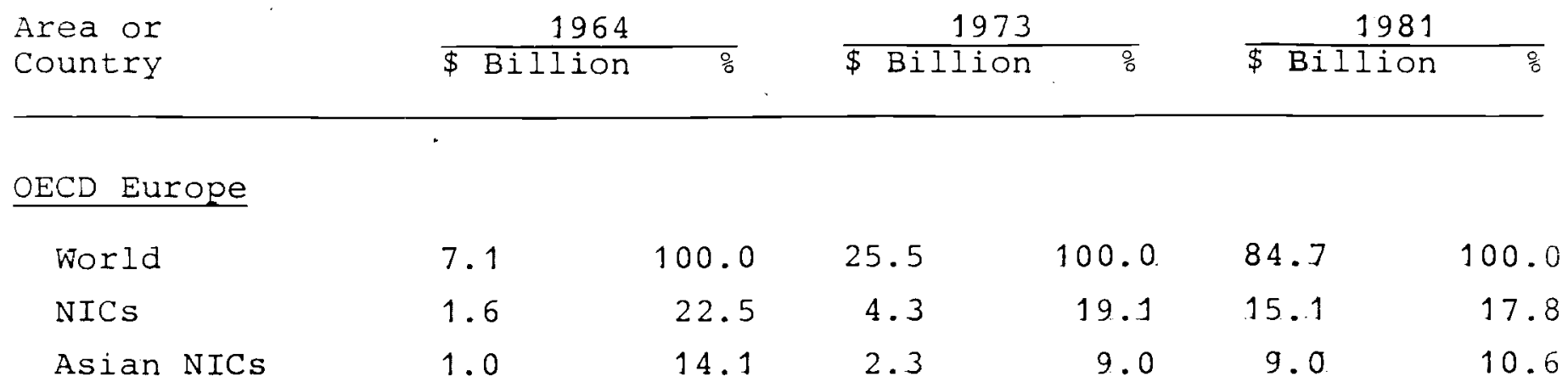

EEC

$\begin{array}{lrrrrrr}\text { World } & 8.7 & 100.0 & 30.1 & 100.0 & 89.9 & 100.0 \\ \text { NICs } & 1.4 & 16.1 & 3.6 & 12.0 & 12.5 & 13.9 \\ \text { Asian NICs } & 1.0 & 11.5 & 1.9 & 6.3 & 7.9 & 8.8\end{array}$

U.S.A.

$\begin{array}{lrrrrrr}\text { World } & 7.9 & 100.0 & 22.6 & 100.0 & 82.2 & 100.0 \\ \text { NICs } & 1.2 & 15.2 & 4.0 & 17.7 & 18.1 . & 22.0 \\ \text { Asian NICs } & 0.5 & 6.2 & 2.4 & 10.6 & 8.0 & 9.7\end{array}$

Japan

$\begin{array}{lrrrrrr}\text { World } & 1.5 & 100.0 & 11.9 & 100.0 & 51.7 & 100.0 \\ \text { NICs } & 0.5 & 33.3 & 3.0 & 25.2 & 14.2 & 27.5 \\ \text { Asian NICs } & 0.4 & 26.7 & 2.9 & 24.4 & 11.9 & 23.0\end{array}$

Source: OECD Data Tape 
Exports of consumder goods are shown in Table 12. Here the U.S. was a major exporter after World War II, but returned to its normal position of net importer as Europe and Japan grew. This restoration of the pre-war pattern of trade is described in Branson (1981, 1983). By 1981 Europe was the largest exporter, Japan second, and the U.S. third. The NIC share of U.S. exports was close to that of Japanese exports, though, much higher than that of European exports, with the U.S. concentrated on Latin American and Japan in Asia.

Finally, exports of other manufactured products are shown in Table 13. These include military equipment and automototive products. [Note: These will be presented separately in the revised version of this paper.] Here, as in consumer goods, Japan is the largest exporter, followed by Europe and then the U.S. The U.S., however, has the largest fraction going to the NICs, heavily concentrated on Latin America. The NIC share of U.S. exports rose from 1973 to 1981, while their share of European and Japanese exports fell.

\subsection{Distribution of Manufactures Exports by Commodity Group.}

The evolution of the distribution of each areas' exports of manufactures across commodity group is shown in Table 14. This table gives the distribution of the totals from Table 7 across the one-digit categories of Tables $9-13$.

The main impression one gets from Table 14 is the relatively static composition of OECD Europe's and the EEC's manufactures exports from 1964 to 1981 , compared especially with the large changes in this composition for Japan, with the U.S. in between. The share of industrial materials 
Table 12: Distribution of Exports of Miscellaneous Manufactures (Consumer Goods) (SITC 8)

\begin{tabular}{|c|c|c|c|c|c|c|}
\hline \multirow{2}{*}{$\begin{array}{l}\text { Area or } \\
\text { Country }\end{array}$} & \multicolumn{2}{|c|}{1964} & \multicolumn{2}{|c|}{1973} & \multicolumn{2}{|c|}{1981} \\
\hline & $\overline{\$ 5}$ & $\overline{\frac{O}{2}}$ & $\overline{\$}$ & $\frac{\bar{g}}{5}$ & $\$ B$ & $\frac{\circ}{\circ}$ \\
\hline OECD Europe & & & & & & \\
\hline World & 2.0 & 100.0 & 6.4 & 100.0 & 20.1 & 100.0 \\
\hline NICs & 0.2 & 10.0 & 0.6 & 9.4 & 2.0 & 10.0 \\
\hline Asian NICs & -- & -- & 0.4 & 6.3 & 1.3 & 6.5 \\
\hline
\end{tabular}

$\underline{\text { EEC }}$

World

2.3

100.0

7.7

100.0

23.5

100.0

NICS

0.1

4.3

0. 4

5.2

1.2

5.1

Asian NICs

0.2

2.6

0.9

3.8

U.S.A.

$\begin{array}{lrrrrrr}\text { World } & 1.3 & 100.0 & 2.7 & 100.0 & 10.0 & 100.0 \\ \text { NICs } & 0.1 & 7.7 & 0.3 & 11.1 & 1.7 & 17.0 \\ \text { Asian NICs } & -- & -- & 0.1 & 3.7 & 0.6 & 6.0\end{array}$

Japan

World

0.8

100.0

2.9

100.0

14.5

100.0

NICs

Asian NICs

$--\quad 0.5$

17.2

2.8

19. 3

0.5

17.2

2.5

17.2 
30.

Table 13: Distribution of Other Manufactured Exports

(including Autos) (SITC 9 plus 38)

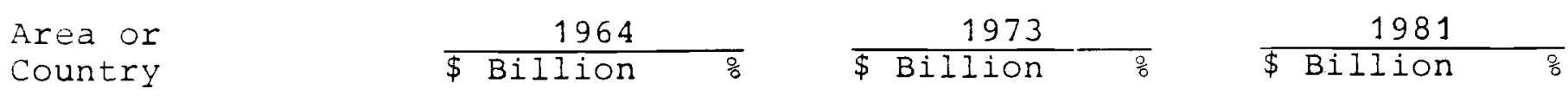

OECD Europe

$\begin{array}{lrrrrrr}\text { World } & 3.3 & 100.0 & 10.4 & 100.0 & 32.0 & 100.0 \\ \text { NICs } & 0.4 & 12.1 & 0.8 & 7.7 & 3.0 & 9.4 \\ \text { Asian NICs } & 0.3 & 9.1 & 0.5 & 4.8 & 1.7 & 5.3\end{array}$

$\underline{\text { EEC }}$

$\begin{array}{lrrrrrr}\text { World } & 4.4 & 100.0 & 13.6 & 100.0 & 38.6 & 100.0 \\ \text { NICs } & 0.4 & 10.0 & 0.6 & 4.4 & 2.6 & 6.7 \\ \text { Asian NICs } & 0.2 & 4.5 & 0.3 & 2.2 & 1.3 & 3.3\end{array}$

U.S.A.

$\begin{array}{lrrrrrr}\text { World } & 2.6 & 100.0 & 8.7 & 100.0 & 24.3 & 100.0 \\ \text { NICs } & 0.5 & 19.2 & 0.9 & 10.3 & 3.6 & 14.8 \\ \text { Asian NICs } & 0.1 & 3.8 & 0.2 & 2.3 & 0.7 & 2.9\end{array}$

Japan

$\begin{array}{lrrrrrr}\text { World } & 0.5 & 100.0 & 6.5 & 100.0 & 39.2 & 100.0 \\ \text { NICs } & 0.2 & 40.0 & 1.0 & 15.4 & 5.1 & 13.0 \\ \text { Asian NICs } & 0.2 & 40.0 & 1.0 & 15.4 & 4.5 & 11.5\end{array}$

Source: OECD Data Tape 
(SITC 6) in OECD exports fell from 27.6 percent in 1964 to 23.9 percent in 1981, while the share of capital goods (SITC 7) rose from 33.8 percent to 38.6 percent. The other categories remained roughly constant.

The composition of U.S. manufactures exports is dominated by a high and rising share of capital goods (SITC 7), from 45.9 percent in 1964 to 51.4 percent in 1981. The shares of industrial materials (SITC 6) and consumer goods (SITC 8) fell across this period.

The structure of Japanese manufactures exports shows major changes in all categories from 1964 to 1981 . The biggest changes are the continuous rise in the share of other manufactures (mainly autos) (SITC 9), the jump in the share of capital goods (SITC 7) from 25.4 percent in 1964 to 35.2 percent in 1973 , with a much slower increase after 1973 , and the decrease in the share of industrial materials, which dominated the distribution in 1964 .

Comparison of the structure of manufactures exports in 1981 across the three major areas shows Japan with a significantly lower share in chemicals (SITC 5), and higher share in other manufactures (mainly autos) (SITC 9) than the U.S. or Europe, and the U.S. with a significantly higher share in capital goods (SITC 7) than Europe or Japan. In a sense, relative to the other areas, Japan seems to be specializing in SITC 9, and the U.S. in SITC 7 , with no single commodity group standing out in OECD Europe or the EEC. 
Table 14: Distribution of Manufactures Exports by Commodity Group

\begin{tabular}{|c|c|c|c|c|c|c|}
\hline \multirow{2}{*}{$\begin{array}{l}\text { Areas or } \\
\text { Country }\end{array}$} & \multicolumn{2}{|l|}{1964} & \multicolumn{2}{|c|}{1973} & \multicolumn{2}{|c|}{1981} \\
\hline & \$billion & $\%$ & \$billion & $\%$ & \$billion & $\%$ \\
\hline \multicolumn{7}{|c|}{ OECD Europe } \\
\hline Total & 21.0 & 100.0 & 69.5 & 100.0 & 219.5 & 100.0 \\
\hline 5 & 2.8 & 13.3 & 9.2 & 13.2 & 30.2 & 13.7 \\
\hline 6 & 5.8 & 27.6 & 18.0 & 25.9 & 52.5 & 23.9 \\
\hline 7 & 7.1 & 33.8 & 25.5 & 36.7 & 84.7 & 38.6 \\
\hline 8 & 2.0 & 9.5 & 6.4 & 9.2 & 20.1 & 9.2 \\
\hline 9 & 33.3 & 15.7 & 10.4 & . 15.0 & 32.0 & 14.0 \\
\hline \multicolumn{7}{|l|}{ EEC } \\
\hline$\overline{\text { Total }}$ & 25.6 & 100.0 & 84.4 & 100.0 & 241.4 & 100.0 \\
\hline 5 & 3.3 & 12.9 & 11.3 & 13.4 & 34.4 & $1+.2$ \\
\hline 6 & 6.9 & 26.9 & 21.7 & 25.7 & 55.0 & 22.7 \\
\hline 7 & 8.7 & 34.0 & 30.1 & .35 .7 & 89.9 & 37.2 \\
\hline 8 & 2.3 & 9.0 & 7.7 & 9.1 & 23.5 & 9.7 \\
\hline 9 & 4.4 & 17.2 & 13.6 & 16.1 & 38.6 & 16.0 \\
\hline \multicolumn{7}{|l|}{ US } \\
\hline Total & 17.2 & 100.0 & 46.5 & 100.0 & 160.0 & 100.0 \\
\hline 5 & 2.4 & 13.9 & 5.7 & 12.2 & 23.3 & 14.6 \\
\hline 6 & 3.0 & 17.4 & 6.8 & 14.6 & 20.2 & 12.0 \\
\hline 7 & 7.9 & 45.9 & 22.6 & 48.6 & 82.2 & 51.4 \\
\hline 8 & 1.3 & 7.6 & 2.7 & 5.8 & 10.0 & 5.3 \\
\hline 9 & 2.6 & 15.1 & 8.7 & 18.7 & 24.3 & 15.2 \\
\hline \multicolumn{7}{|l|}{ Japan } \\
\hline$\overline{\text { world }}$ & 5.9 & 100.0 & 33.8 & 100.0 & 144.9 & 100.0 \\
\hline 5 & 0.4 & 6.8 & 2.1 & 6.2 & 0.3 & 4.7 \\
\hline 6 & 2.7 & 45.8 & 10.4 & 30.8 & 32.7 & 22.6 \\
\hline 7 & 1.5 & 25.4 & 11.9 & 35.2 & 51.7 & $\vdots$ \\
\hline 8 & 0.8 & 13.6 & 2.9 & 8.6 & 14.5 & $\therefore \ldots$ \\
\hline 9 & 0.5 & 8.5 & 6.5 & 19.2 & 39.2 & $2-i$ \\
\hline
\end{tabular}

Source: OECD Data Tape

Note: Percentages may not total to 100 due to rounding error Definitions of Commodity Groups on SITC Revision 2:

SITC 5: Chemicals and related products

SITC 6: Manufactures classified chiefly by material, i.e. industrial supplies and materials. SITC 676 (rails and railway track), 692 (metal containers), 695 (tools for hand or machine use), were subtracted from SITC 6 and added to.SITC 7

SITC 7: Capital goods. SITC 676, 692, and 695 were added. SITC 775 (domestic electrical equipment) and 78 (road vehicles) were subtracted from SITC 6 and added to SITC 9. SITC 87 (professional, scientific, and controlling apparatus) was subtracted from SITC 8 and added to SITC 7

SITC 8: Miscellaneous manufactured goods (mainly consumer manufactures) SITC 87 was moved to SITC 7

SITC 9: Commodities and transactions not elsewhere classified plus SITC 775 and 78. This is also military equipment plus autos. 


\subsection{Conclusion.}

In Table 11 we saw that a high and rising share of U.S. capital goods exports goes to the NICs. This share reached 22 percent in 1981, with 9.7 percent going to the Asian NICs, and 11.3 percent to Latin America. Then in Table 14 we saw that U.S. exports of manufactures are dominated by capital goods exports to a degree that no one-digit commodity reaches in Europe of Japan. By 1981, over half of U.S. exports of manufactures were capital goods.

Thus rapid growth and high levels of investment in the NICs have been associated with rapid growth and concentration in U.S. exports of capital goods, and this association seems strongest with the Latin American NICs. This has contributed to an increasing interdependence of the U.S. economy with the NICs, an interdependence that could have important implications for U.S. foreign economic policy. 


\section{The Structure of OECD Imports.}

\subsection{Introduction.}

There have been two striking developments (aside from OPEC) in the structure of OECD imports from the leading developing countries in the two decades since 1964. The first has been the change in the structure of European and U.S. imports of manufactured goods, mainly away from industrial supplies and materials and toward consumer goods, capital goods, and automotive products. The other has been the rise of the NICs, especially since 1970, as the source of manufactured imports to Europe and the U.S. This has been most striking in consumer goods, where the NICs provided nearly 40 percent of European imports and 50 percent of U.S. imports by 1980.

As is well-known, the level of Japanese manufactures imports remains low relative to the U.S. and Europe. Basically, the Japanese economy exports manufactures and imports non-manufactures due to its relatively poor resource base. Fully 95 percent of Japanese exports are manufactures, but only 21 percent of Japanese imports. Comparable numbers for the U.S. are 70 percent on the export side and 55 percent on the import side. However, the fraction of Japanese and U.S. total manufactures imports coming from the NICs are almost the same, a bit over 20 percent. As on the export side, the proportion of European manufactures imports coming from the NICs is smaller, under 15 percent in 1980.

The evolution of total imports, total imports less fuel, and total manufactures imports, and their distribution by source, is shown in 
Tables 15-17 for OECD Europe, the U.S., and Japan. [Note: Tables 15-23 will be up-dated to 1981 and to include EEC in revision. The import tape was not available when this was written.]. The total import data are sufficiently influenced by oil prices since 1973 that we will begin by focusing on Table 16, which gives total imports less fuel.

In Table 16, we see that U.S. and Japanese imports grew much faster than European imports from 1964 to 1973. Then from 1973 to 1980 growth rates were much more equal, with European imports growing fastest and the U.S. slowest. The fraction of European non-fuel imports coming from the identified NICs rose slowly throughout the period to 17.3 percent 1964-80. The share of the NICs in U.S. imports was constant for 1964 to 1973, and then increased significantly to 23 percent by 1980 . The share of the NICs on Japanese non-fuel imports increased rapidly over the entire period, reaching 40 percent by 1980 . In contrast to the export data, on the import side at this level of aggregation, both Europe and the U.S. imports from the NICs are relatively more concentrated on Asia than are the Japanese.

The data on total manufacturing imports are summarized in Table 17. There we see the difference between the levels of imports of Europe and the U.S., and of Japan. However from 1964 to 1980, Japanese manufactured imports grew at the same rate as those of the U.S.; in 1964 their ratio is 0.21 , by 1980 it was 0.22 . European manufactures imports grew faster, though, especially after 1973. The ratio of European to U.S. manufactures imports rose from 0.79 in 1964 to 0.81 in 1973 , and then jumped to 1.05 in 1980. 
Table 15: Distribution of Total Imports.

\begin{tabular}{|c|c|c|c|c|c|c|}
\hline \multirow{2}{*}{$\begin{array}{l}\text { Area or } \\
\text { Country }\end{array}$} & \multicolumn{2}{|l|}{1964} & \multicolumn{2}{|l|}{1973} & \multicolumn{2}{|l|}{1980} \\
\hline & \$Billion & $\overline{\frac{9}{0}}$ & \$ Billion & $\overline{\frac{9}{0}}$ & \$Billion & $\overline{\frac{O}{0}}$ \\
\hline OECD Europe & & & & & & \\
\hline World & 36.1 & 100.0 & 98.2 & 100.0 & 373.0 & 100.0 \\
\hline NICs & 4.2 & 11.6 & 12.0 & 12.2 & 41.0 & 11.0 \\
\hline Asian NICs & 2.1 & 5.8 & 6.1 & 6.2 & 25.5 & 6.8 \\
\hline U.S.A. & & & & & & \\
\hline World & 18.6 & 100.0 & 69.5 & 100.0 & 250.3 & 100.0 \\
\hline NICs & 2.9 & 15.6 & 11.0 & 15.8 & 50.9 & 20.3 \\
\hline Asian NICs & 1.4 & 7.5 & 6.8 & 9.8 & 32.1 & 12.8 \\
\hline
\end{tabular}

\section{Japan}

$\begin{array}{lrrrrrr}\text { World } & 7.9 & 100.0 & 38.1 & 100.0 & 139.9 & 100.0 \\ \text { NICs } & 1.1 & 13.9 & 8.1 & 21.2 & 31.4 & 22 . \\ \text { Asian NICs } & 0.9 & 11.4 & 7.8 & 20.5 & 28.4 & 20.3\end{array}$


37.

Table 16: Distribution of Total Imports Less Fuel (SITC 3)

\begin{tabular}{|c|c|c|c|c|c|c|}
\hline \multirow{2}{*}{$\begin{array}{l}\text { Area or } \\
\text { Country }\end{array}$} & \multicolumn{2}{|c|}{1964} & \multicolumn{2}{|c|}{1973} & \multicolumn{2}{|c|}{1980} \\
\hline & $\$ \mathrm{bill}$ & $\%$ & \$billion & $\%$ & \$billion & $\%$ \\
\hline \multicolumn{7}{|l|}{ OECD Europe } \\
\hline $\begin{array}{l}\text { World } \\
\text { NICs } \\
\text { Asian NICs }\end{array}$ & $\begin{array}{r}29.5 \\
4.2 \\
2.1\end{array}$ & $\begin{array}{r}100.0 \\
14.2 \\
7.1\end{array}$ & $\begin{array}{r}75.2 \\
12.0 \\
6.1\end{array}$ & $\begin{array}{r}100.0 \\
16.0 \\
8.1\end{array}$ & $\begin{array}{r}223.1 \\
38.7 \\
25.3\end{array}$ & $\begin{array}{r}100.0 \\
17.3 \\
11.3\end{array}$ \\
\hline \multicolumn{7}{|l|}{ U.S.A. } \\
\hline $\begin{array}{l}\text { World } \\
\text { NICs } \\
\text { Asian NICs }\end{array}$ & $\begin{array}{r}16.6 \\
2.7 \\
1.4\end{array}$ & $\begin{array}{r}100.0 \\
17.5 \\
8.4\end{array}$ & $\begin{array}{r}61.3 \\
10.8 \\
6.6\end{array}$ & $\begin{array}{r}100.0 \\
17.6 \\
10.8\end{array}$ & $\begin{array}{r}168.0 \\
38.7 \\
26.7\end{array}$ & $\begin{array}{r}100.0 \\
23.0 \\
15.9\end{array}$ \\
\hline \multicolumn{7}{|l|}{ Japan } \\
\hline $\begin{array}{l}\text { World } \\
\text { NICs } \\
\text { Asian NICs }\end{array}$ & $\begin{array}{l}6.5 \\
1.0 \\
0.8\end{array}$ & $\begin{array}{r}100.0 \\
15.4 \\
12.3\end{array}$ & $\begin{array}{r}29.8 \\
6.4 \\
6.1\end{array}$ & $\begin{array}{r}100.0 \\
21.5 \\
20.5\end{array}$ & $\begin{array}{l}69.6 \\
27.9 \\
15.2\end{array}$ & $\begin{array}{r}100.0 \\
40.0 \\
21.8\end{array}$ \\
\hline
\end{tabular}

Source: OECD Commodity Series C 
Table 17: Distribution of Imports of Manufactures (SITC 5-9)

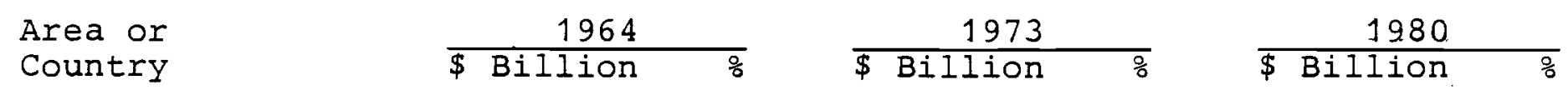

\section{OECD Europe}

$\begin{array}{lrrrrrr}\text { World } & 7.6 & 100.0 & 38.2 & 100.0 & 142.9 & 100.0 \\ \text { NICs } & 0.6 & 7.9 & 3.7 & 9.7 & 20.9 & 14.6 \\ \text { Asian NICs } & 0.6 & 7.9 & 3.3 & 8.6 & 18.4 & 12.9\end{array}$

U.S.A.

$\begin{array}{lrrrrrr}\text { World } & 9.6 & 100.0 & 46.8 & 100.0 & 136.2 & 100.0 \\ \text { NICs } & 0.6 & 6.3 & 6.8 & 14.5 & 27.4 & 20.1 \\ \text { Asian NICs } & 0.5 & 5.2 & 5.1 & 10.9 & 21.5 & 15.9\end{array}$

Japan

$\begin{array}{lrrrrrr}\text { World } & 2.0 & 100.0 & 11.7 & 100.0 & 30.4 & 100.0 \\ \text { NICs } & -- & -- & 1.8 & 15.4 & 6.3 & 20.7 \\ \text { Asian NICS } & -- & -- & 1.7 & 14.5 & 5.0 & 16.4\end{array}$


The proportion of manufactures imports coming from the NICs has increased over time in all three areas, with the biggest increase in Japan, especially from 1964 to 1973, and the smallest in Europe. By 1980, rough1y 20-21 percent of U.S. and Japanese manufactured imports came from the NICs, as compared with 15 percent of European imports. Again, in contrast to the export pattern, all three areas' imports of manufactures from the NICs are concentrated in Asia, relative to Latin America.

\subsection{Disaggregation of the Distribution of Manufactures Imports by Origin.}

The distributions of manufactures imports for the one-digit SITC categories are shown in Tables 18-22. The categories are the same as for exports; details are given in the note to Table 14.

Chemical imports, summarized in Table 18, are small, with the largest total $\$ 14.6$ billion in Europe in 1980. Relative to the other areas, the U.S. has a higher proportion coming from the Latin American NICs, and Japan from the Asian NICs, but the numbers are small. Imports of industrial supplies are summarized in Table 19. There we see low numbers for Japan relative to the other areas, with a high concentration on the Asian NICs. By 1980 Europe was a bigger importer than the U.S., but they had similar contributions. Table 20 summarizes the distribution of imports of capital goods. The world totals are similar to those of industrial supplies, with OECD Europe imports in 1980 of $\$ 48.6$ billion, compared to $\$ 37.8$ billion for the U.S., and $\$ 8.7$ billion for Japan. There is a significant difference in the distribution by source, however, both across importing areas in Table 20 , and by comparison with industrial supplies in Table 19. In 1980, 22 percent of U.S. imports of 
40.

Table 18: Distribution of Imports of Chemical Products (SITC 5)

\section{OECD Europe}

World

1.3

$100.0 \quad 4: 2$

10.0.0. 14.6.

10.0 .0

NICS

$-$

--

0.4

2.7

Asian NICs

- $\quad--$

--

0.1 .

0.7

U.S.A.

$\begin{array}{lrrrrrr}\text { World } & 0.7 & 100.0 & 2.5 & 100.0 & 9.0 & 100.0 \\ \text { NICs } & -- & -- & -- & -- & 0.5 . & 5.5 \\ \text { Asian NICs } & -- & -- & -- & -- & 0.1 & 1.1\end{array}$

$\underline{\text { Japan }}$

World

0.5

$100.0 \quad 1.9$

100.0

5.9

100.0

NICs

--

-- 0.5

8.5

Asian NICs

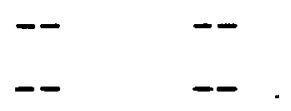

-- 0.4

6.8 
Table 19: Distribution of Imports of Industrial Supplies and

Materials other than Fuel, (SITC 6)

Area or

Country $\frac{1964}{\$ \text { Billion }}$ $\frac{1973}{\$ \text { Billion }}$ $\frac{1980}{\$ \text { Billion } \frac{9}{0}}$

\section{OECD Europe}

World

NICS

Asian NICs
4.6

0.3

0.3
$100.0 \quad 14.1$

6.51 .7

6.51 .3

$\begin{array}{rr}100.0 & 41.8 \\ 12.1 & 6.7 \\ 9.2 & 5.2\end{array}$

100.0

16.0

12.4

U.S.A.

$\begin{array}{lrrrrrr}\text { World } & 4.5 & 100.0 & 13.0 & 100.0 & 33.5 & 100.0 \\ \text { NICs } & 0.4 & 8.9 & 2.0 & 15.4 & 5.7 & 17.0 \\ \text { Asian NICs } & 0.3 & 6.7 & 1.4 & 10.8 & 4.2 & 12.5\end{array}$

Japan

World

0.6

10.0 .0

4.5

100.0

9.7

100.0

NICs

Asian NICs

$--$

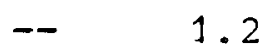

26.7

2.7

27.8

$-1 \quad 1.1$

24.4

2.3

23.7

Source: OECD Commodity series C 
Area or

Country $\frac{1964}{\$ \text { Billion }}$ $\frac{1973}{\$ \text { Billion } \frac{9}{3}}$ $\frac{1980}{\$ \text { Billion } \frac{\circ}{0}}$

\section{OECD Europe}

$\begin{array}{lrrrrrr}\text { World } & 0.4 & 100.0 & 12.3 & 100.0 & 48.6 & 100.0 \\ \text { NICs } & -- & -- & 0.3 & 2.4 & 3.8 & 7.8 \\ \text { Asian NICS } & -- & -- & 0.3 & 2.4 & 3.5 & 7.2\end{array}$

U.S.A.

$\begin{array}{lrrrrrr}\text { World } & 1.5 & 100.0 & 11.2 & 100.0 & 37.8 & 100.0 \\ \text { NICs } & -- & -- & 2.1 & 18.8 & 8.4 & 22.2 \\ \text { Asian NICs } & -- & -- & 1.4 & 12.5 & 6.1 & 16 .\end{array}$

\section{Japan}

World

NICs

Asian NICs

\begin{abstract}
0.8
\end{abstract}
$--$

$-$

\begin{abstract}
$100.0 \quad 3.1$
\end{abstract}
$-$
100.0

--

$-$
8.7

$1.5^{-1-}$

0.7
100.0

17.2

8.0

Includes $\$ 0.7$ billion from Argentina in 1980 .

Source: OECD Commodity Series $C$ 
comparison with industrial supplies in Table 18. In 1980, 22 percent of U.S. imports of capital goods came from the NICs, 16 percent from Asia. The proportions for Europe and Japan are much smaller, with the Japanese share for Latin America all coming from Argentina. [Note: We are checking the data to see if this is a good observation]. The U.S. is a much bigger importer of capital goods from the NICs, especially in Asia, than are Europe or Japan.

The distribution of consumer goods imports is shown in Table 21. Here the total imports are smaller than for industrial supplies or capital goods, but the concentration on the NICs, especially in Asia, is much stronger. Out of roughly equal total consumer goods imports of \$23-24 billion in 1980, nearly half of U.S. imports and 40 percent of European imports come from the NICs, mostly from Asia. The U.S. share has risen much more rapidly over time than the European share. U.S. and European imports of consumer goods from the NICs are greater than any of the other one-digit categories as a result of this concentration. Japan also has a relatively high share of consumer goods imports from the Asian NICs, but out of a very small total.

Imports of the other category, which includes arms and autos, are summarized in Table 22. Here we see the relatively high level of U.S. imports in 1980, and the rapid growth of both European and U.S. imports over the entire period since 1964. The NIC shares of these imports are very small, however. NIC exports of manufactures to the OECD countries are concentrated in industrial supplies, capital, goods, and especially consumer goods, with very small NIC export participation in chemicals or autos. 
Table 21: Distribution of Imports of Consumer Goods

(less Autos.) (SITC 8)

Area or

country

$\frac{1964}{\$ \text { Billion }}$

0.9

100.0

5.3

100.0

23.9

32.0

9. 5

32.0

9. 3

33.31 .7

0.3

1.7

$100.0 \quad 7.6$

100.0

$23 \cdot 3$

100

13.32 .5

32.9

11.4

48.9

13.32 .2

28.9

10.3

44.2

\section{Japan}

$\begin{array}{lrrrrrr}\text { World } & 0.1 & 100.0 & 1.8 & 100.0 & 4.5 & 100.0 \\ \text { NICs } & -- & -- & 0.6 & 33.3 & 1.5 & 33.2 \\ \text { Asian NICs } & -- & -- & 0.6 & 33.3 & 1.5 & 33.3\end{array}$


Table 22: Distribution of Imports of Commodities

not elsewhere classified (Arms and Autos)

(SITC 9)

Area or

Country $\frac{1964}{\$ \text { Billion }}$

0.4

$100.0 \quad 2.4$

$--\quad-$

Asian NICs

U.S.A.

World

NICS

Asian NICs

1. 4

$100.0 \quad 12.5$

0.2

$-$

$--$

0.1

$--$

$--$

$--$

1973 $\frac{1980}{\$ \text { Billion }}$

Japan

$\begin{array}{lrrrrrr}\text { World } & 0.0 & -- & 0.4 & 100.0 & 1.6 & 100.0 \\ \text { NICs } & -- & -- & -- & -- & 0.1 & 6.3 \\ \text { Asian NICs } & -- & -- & -- & -- & 0.1 & 6.3\end{array}$

Source: OECD Commodity Series C 


\subsection{Distribution of Manufactures Imports by \\ Commodity Group.}

The distributions across commodity groups are given in Table 23 . Here the main impression is of change in the structure of manufactures imports over time in Europe and the U.S., and stability in Japan, at least since 1973. By 1980 the U.S. structure was more "balanced" than that of Europe or Japan. The distributional peaks are 34 percent in European capital goods imports, 32 percent for industrial supplies in Japan, and 29 percent for industrial supplies in Europe and capital goods in Japan. (Remember that in all cases the Japanese totals are relatively sma11.)

In Europe, the major movement has been away from imports of industrial supplies, with a share falling from 60.5 percent in 1964 to 29.3 percent in 1980 , and to a lesser extent chemicals, where the share fell from 17.1 percent in 1964 to 10.7 percent in 1973. The biggest increase in import share in Europe came in capital goods, from 5.3 percent in 1963 to 34 percent by 1980. Smaller but significant increases came in their shares of consumer goods and other (auto) imports.

In the U.S., the main shifts in the structure of manufactures imports came between 1964 and 1973. In this period the share of industrial supplies fell from 46.9 to 27.8 percent, while the share of capital goods rose from 15.6 to 23.9 percent, and that of other manufacture (autos) rose from 14.6 to 26.7 percent. Since 1973 the composition of U.S. manufactured exports has been relatively stable, and more balanced across categories than in Europe or Japan. 
Table 23: Distribution of Manufactures Imports by Commodity Group

Area or

Country

$\frac{1964}{\$ \text { Billion }}$

$\frac{1973}{\$ \text { Billion }}$ $\frac{1980}{\$ \text { Billion }}$

\section{OECD Europe}

$\begin{array}{crrrrrr}\text { Total } & 7.6 & 100.0 & 38.2 & 100.0 & 142.9 & 100.0 \\ 5 & 1.3 & 17.1 & 4.1 & 10.7 & 14.6 & 10.2 \\ 6 & 4.6 & 60.5 & 14.1 & 36.9 & 4.1 .8 & 29.3 \\ 7 & 0.4 & 5.3 & 12.3 & 32.2 & 48.6 & 34.0 \\ 8 & 0.9 & 11.8 & 5.3 & 13.9 & 23.9 & 16.7 \\ 9 & 0.4 & 5.3 & 2.4 & 6.3 & 14.0 & 9.8\end{array}$

\section{$\underline{U . S . A}$}

$\begin{array}{crrrrrr}\text { Total } & 9.6 & 100.0 & 46.8 & 100.0 & 136.2 & 100.0 \\ 5 & 0.7 & 7.3 & 2.5 & 5.3 & 9.0 & 6.6 \\ 6 & 4.5 & 46.9 & 13.0 & 27.8 & 33.5 & 24.6 \\ 7 & 1.5 & 15.6 & 11.2 & 23.9 & 37.8 & 27.8 \\ 8 & 1.5 & 15.6 & 7.2 & 16.2 & 23.3 & 17.1 \\ 9 & 1.4 & 14.6 & 12.5 & 26.7 & 32.6 & 23.9\end{array}$

Japan

$\begin{array}{crrrrrr}\text { Total } & 2.0 & 100.0 & 11.7 & 100.0 & 30.4 & 100.0 \\ 5 & 0.5 & 25.0 & 1.9 & 16.2 & 5.9 & 19.4 \\ 6 & 0.6 & 30.0 & 4.5 & 38.5 & 9.7 & 31.9 \\ 7 & 0.8 & 40.0 & 3.1 & 26.5 & 8.7 & 28-6 \\ 8 & 0.1 & 5.0 & 1.8 & 15.4 & 4.5 & 14.8 \\ 9 & 0.0 & -- & 0.4 & 3.4 & 1.6 & 5.3\end{array}$

Source: OECD Commodity Series C. Note: Totals may not all due to rounding 


\subsection{Conclusion.}

Among the OECD areas, Europe and the U.S, are the major importers of manufactured goods, and thus the principal potential markets for the NICs. In Table 17, we see that while European total manufactures imports exceed those of the U.S. in 1980, U.S. imports from both Latin American and Asian NICs--\$5.9 and 21.5 billion respectively--are greater than those of Europe. The U.S. is the largest importer of manufactures from the NICs, especially in Asia, of the three main OECD areas.

Despite the relatively balanced structure of U.S. imports across commodities, the concentration on the NICs as a source, especially in consumer goods but also in capital goods, gives this result. In 1980, the shares of consumer goods imports in U.S. and European total manufactures imports were about the same, 17.1 and 16.7 percent respectively. But the U.S. concentration on the NICs, with a 48.9 percent share of the U.S. market, compared to 39.7 in Europe, resulted in U.S. imports from the NICs of $\$ 11.5$ billion in consumer goods. This was the largest single NIC export category to an OECD area in 1980 . The $\$ 10.3$ billion of Asian NIC consumer good exports to the U.S. was the largest single category for that sub-group in 1980.

Thus on the side of NIC exports of manufactures to the OECD, the U.S. is the largest importer, in spite of (a) a larger import total in Europe, and (b) more balance of U.S. imports across commodities. This imbalance in U.S. imports in favor of the NICs as a source adds to the impression of a growing interdependence of the U.S. economy with the NICs, as an exporter, mainly of capital goods mainly to Latin America, and an importer of consumer goods, mainly from Asia. 
5. U.S. Trade with the NICs.

The previous sections of this paper have compared the trade patterns of the U.S., Japan, and Europe with the NICs, both Asian and Latin American. Here we focus in more detail on the structure of U.S. trade by one-digit SITC category with the individual NICs.

First, in Table 24, we show the evolution of total U.S. manufactures trade by commodity group from 1973 to 1980 . The data in nominal terms can be seen in Tables 14 and 23. In 1973 U.S. manufactures exports were $\$ 46.5$ billion, and imports $\$ 46.8$ billion--almost exactly balanced. In 1980 , exports had increased to $\$ 149.4$ billion and imports to $\$ 136.2$ billion, for a surplus of $\$ 13.2$ billion. But much of that increase was inflation, so in Table 24 we show that the data deflated to 1973 prices. The surplus on overall manufactures exports, in real terms, went from zero to 6.8 billion (1973 prices) by 1980. Over a period when the U.S. economy grew by about 2.5 percent per year (on average) in real terms, manufactures exports grew by 9.8 percent a year, and manufactures imports grew by 8.6 percent per year. This is hardly a picture of a "deindustrializing" economy; rather it reflects a rapid change in the structure of U.S. industrial production, with export sectors drawing resources from shrinking, import-competing sectors.

The structure of U.S. trade in manufactures with the NICs in 1980 is shown in Table 25. There the countries are separated between the Asian and Latin American NICs, and within each group, the NICs and the "new NICs." At the bottom we present an ASEAN aggregate--Singapore, Indonesia, Malaysia, the Philippines, and Thailand. Data are given for 
Table 24: U.S. Trade in Manufactures in Constant 1973 Dollars, 1973-1980 (\$ billion)

\begin{tabular}{|c|c|c|c|c|}
\hline \multirow[b]{2}{*}{ Commodity } & \multicolumn{2}{|c|}{$\underline{1973}$} & \multicolumn{2}{|c|}{1980} \\
\hline & Exports & Imports & Exports & Imports \\
\hline & • & & & \\
\hline Chemicals (SITC 5) & 5.7 & 2.5 & 14.1 & 5.6 \\
\hline $\begin{array}{l}\text { Industrial Supplies } \\
\text { (SITC 6) }\end{array}$ & 6.8 & 13.0 & 13.4 & 20.7 \\
\hline $\begin{array}{l}\text { Capital Goods } \\
\quad(\text { SITC } 7)\end{array}$ & 22.6 & 11.2 & 43.7 & 22.8 \\
\hline $\begin{array}{l}\text { Consumer Goods } \\
\quad \text { (SITC 8) }\end{array}$ & 2.7 & 7.6 & 6.8 & 15.2 \\
\hline $\begin{array}{l}\text { Other Manufactures } \\
\text { (SITC 9) } \\
\text { (Autos and Arms) }\end{array}$ & 8.7 & 12.5 & 14.1 & 21.0 \\
\hline Total & 46.5 & 46.8 & 92.1 & 85.3 \\
\hline
\end{tabular}

Sources: 1. OECD Data Tape and Commodities Serices C for trade data in current dollars.

2. Council of Economic Advisers Annual Report, 1983 for price indexes as follows:

Chemicals and Industrial Materials: Total Goods Deflator, Tables B-7 and 8

Capita1 Goods: Deflator for Producers' Durable Equipment, Table B-3

Consumer Goods: Deflator for Consumer Expenditure on Durables, Table B-3

Autos: Auto Product Deflator, Tables B-7 and 8 . 
each of the one-digit SITC categories, and for the total. The balance on the upper right-hand corner of the table is the $\$ 13.2$ billion surplus a1ready mentioned. The first row shows the structure of U.S. world trade in manufactures: surpluses in chemicals and capital goods, deficits in industrial materials, consumer goods, and "other."

Let us focus first on the differences in trade patterns with the Latin American and Asian NICs. In aggregate, U.S. trade with the Asian NICs follows the broad pattern of U.S. world trade, except for balance in SITC 9. But with the Latin American NICs, the U.S. has a surplus in every category except consumer goods, where trade was balanced. Overall, the U.S. had a deficit in manufactures trade of $\$ 6.3$ billion with the Asian NICs, and a surplus of $\$ 12.2$ billion with the Latin Americans. Mexico alone provided a $\$ 6.9$ billion surplus to the U.S. in 1980 , the largest component being capital goods. This highlights the exposure of U.S. trade to the debt situation in Latin America.

Another interesting distinction appears when we separate the Asian NICs into ASEAN and the Far Eastern countries of Hong Kong, S. Korea, and Taiwan. In 1980 the Far Eastern NICs had an aggregate surplus of $\$ 9.3$ billion in trade in manufactures with the U.S., while ASEAN had a $\$ 2.5$ billion deficit, compared with the Latin American deficit of $\$ 12.2$ billion. On balance, the U.S. exports manufactures to Latin America, the Latin American NICs sell non-manufactures (especially Mexican oil) into the wor1d market, the Far Eastern NICs buy non-manufactures and sell manufactures to the U.S. A similar triangle could be drawn between the U.S., ASEAN, and the Far Eastern NICs, with Indonesian oil replacing Mexican. These trade patterns highlight the importance of Latin America and ASEAN 


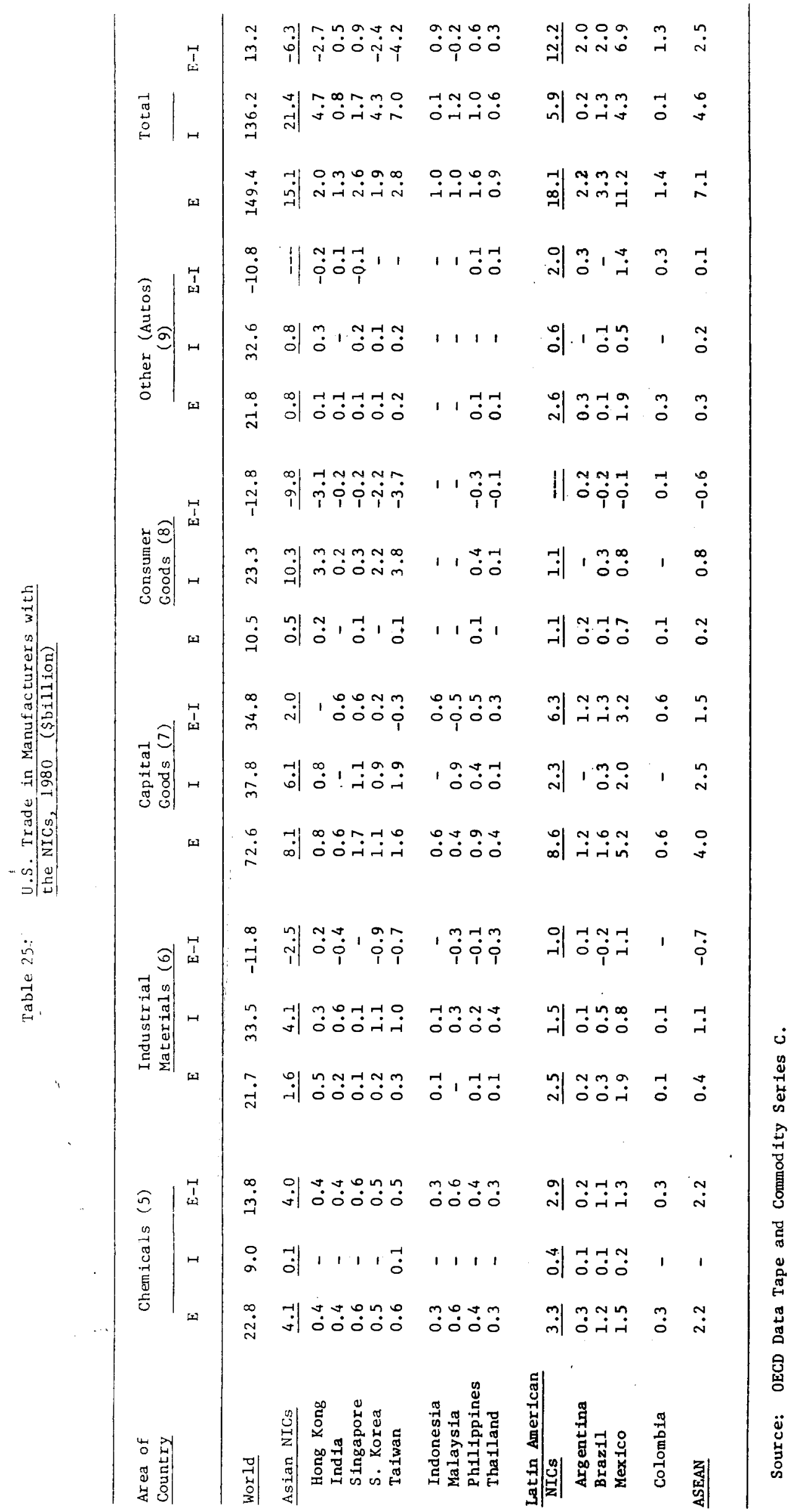


as U.S. export markets, and the U.S. as an export market for the Far Eastern NICs.

The data of Table 25 thus show interesting patterns of imbalance in U.S. manufactures trade both across commodities and geography. Following its lines of comparative advantage, the U.S. is a major exporter of capital goods, chemicals, and military equipment, and importer of industrial materials, consumer goods, and autos. Net exports to the NICs alone provide half the U.S. surplus on chemicals and one-quarter on capital goods; the Asian NICs, mainly the Far Eastern ones supply threequarters of the U.S. deficit on consumer goods. U.S. trade in manufactures has become increasingly interdependent with the three groups of NICs--Latin America, ASEAN (plus India), and Far Eastern. The patterns of interdependence are complicated, and will require increasing attention from U.S. foreign economic policy. 
References:

Bradford, C. (1981), The Role of LDC-NICs in World Economic Adjustment, mimeo, Yale University Concilium on International and Area Studies.

Branson, W. H. (1981), Trends in U.S. Trade and Investment Since World War II, in M. Feldstein (ed), The American Economy in Transition (University of Chicago Press).

(1983), The Myth of Deindustrialization, Regulation v. 7 , No. 5 . 